\title{
Review
}

\section{Biotechnology and apple breeding in Japan}

\author{
Megumi Igarashi $^{\dagger 1}$, Yoshimichi Hatsuyama $^{\dagger 2}$, Takeo Harada ${ }^{3)}$ and Tomoko Fukasawa-Akada*1) \\ 1) Hirosaki Industrial Research Institute, Aomori Prefectural Industrial Technology Research Center, Ogimachi 1-1-8, Hirosaki, Aomori \\ 036-8104, Japan \\ 2) Apple Research Institute, Aomori Prefectural Industrial Technology Research Center, Fukutami 24, Botandaira, Kuroishi, Aomori 036- \\ 0332, Japan \\ 3) Department of Agriculture and Life Science, Hirosaki University, Bunkyouchou 3, Hirosaki, Aomori 036-8563, Japan
}

\begin{abstract}
Apple is a fruit crop of significant economic importance, and breeders world wide continue to develop novel cultivars with improved characteristics. The lengthy juvenile period and the large field space required to grow apple populations have imposed major limitations on breeding. Various molecular biological techniques have been employed to make apple breeding easier. Transgenic technology has facilitated the development of apples with resistance to fungal or bacterial diseases, improved fruit quality, or root stocks with better rooting or dwarfing ability. DNA markers for disease resistance (scab, powdery mildew, fire-blight, Alternaria blotch) and fruit skin color have also been developed, and marker-assisted selection (MAS) has been employed in breeding programs. In the last decade, genomic sequences and chromosome maps of various cultivars have become available, allowing the development of large SNP arrays, enabling efficient QTL mapping and genomic selection (GS). In recent years, new technologies for genetic improvement, such as trans-grafting, virus vectors, and genome-editing, have emerged. Using these techniques, no foreign genes are present in the final product, and some of them show considerable promise for application to apple breeding.
\end{abstract}

Key Words: apple, breeding technology, trans-grafting, DNA marker, QTL-analysis, transgenic, NPBTs.

\section{Introduction}

Fruits are rich in fiber, antioxidants and phytochemicals that have beneficial effects for human health. Apple (Malus $\times$ domestica Borkh.) is one of the most popular fruits, and is considered to be a major functional food resource. Many new apple cultivars with improved fruit quality or growth habits have emerged as a result of the steady efforts of breeders worldwide.

Breeding of new apple cultivars is challenging. The main method of traditional apple breeding has been through the crossing and selection of superior individuals from thousands of seedlings. The lengthy juvenile period of the tree and its large size, requiring a long period of time for evaluation and a large field space, have imposed limitations on apple breeding programs.

Breeding apple cultivars that are resistant to diseases, especially scab caused by the fungus Venturia inaequalis, has also been a major aim of apple breeding programs world-

Communicated by T. Yamamoto

Received August 23, 2015. Accepted December 23, 2015.

*Corresponding author (e-mail: tomoko_akada@aomori-itc.or.jp)

${ }^{\dagger}$ These authors contributed equally to this work wide. Genetic analyses and breeding programs for scab resistance were initiated in 1914, and Dayton et al. (1970) have reported that it took over 50 years to obtain apple cultivars with a scab-resistant trait derived from a wild apple species, although the resulting fruit still did not meet consumer expectations. In Japan, because of the climate and the favored cultivars, Alternaria leaf-blotch, a disease caused by the fungus Alternaria alternarta apple pathotype, has become a major concern among apple growers and breeders since the 1960s. The susceptibility of cultivars and its inheritance have been studied intensively (Saito and Takeda 1984). Five apple cultivars are recognized as the founders of cultivars developed in Japan, and two of them, 'Indo' and 'Delicious', are readily susceptible, with many progeny cultivars inheriting the trait in a dominant manner.

Commercial competition from other fruits has been steadily increasing, and changes in consumer demand have prompted breeders worldwide to develop new apple cultivars with more attractive characteristics and improved benefits.

Rapid developments in biotechnological breeding have shortened the period of time needed for fruit tree breeding, and such techniques are now being applied to apples. Decoding of the apple genome (Velasco et al. 2010) has provided insight into not only the evolution of this species, 
but also information for clarifying the genetic basis of fruit quality, disease resistance, and growth habit. First, the number of solid markers of disease resistance and fruit character has been increasing, and the development of markerassisted selection (MAS) strategies has accelerated. The development of molecular markers has also facilitated the construction of detailed linkage maps for QTL analysis, revealing chromosome regions associated with various apple traits (Bai et al. 2012a, Chagné et al. 2012a, Devoghalaere et al. 2012, Kunihisa et al. 2014). Apple breeding can thus be performed more efficiently using MAS strategies. Second, techniques for tissue culture and gene introduction in apple have been established (Puite and Schaart 1996, Schaart et al. 2011a, 2011b). A gene-modified (GM) line, which does not turn brown when cut, has finally been allowed to enter the marketplace in both Canada and the USA (Carter 2012). On the other hand, public concern about GM crops still persists, mainly with regard to the random insertion of a transgene in the genome and the remnant selectable marker gene. Third, in response to public concerns about GM crops, new plant breeding technologies (NPBTs; Lusser et al. 2012) have been introduced. NPBTs may allow breakthroughs in crop breeding, and have an enormous impact on apple breeding in the near future.

This review discusses the advances achieved so far through biotechnology in relation to apple breeding in Japan. As there have already been several distinguished reviews of apple breeding and biotechnology (Gardiner et al. 2007, Keller-Przybyłkowicz and Korbin 2013, Marić et al. 2010, Pereira-Lorenzo et al. 2009), the present review focuses mainly on recent developments.

\section{Apple production and breeding in Japan}

Over 140 years have passed since apple production was initiated in Japan. In the search for cultivars suitable for consumers and regional cultivation conditions, hundreds of introduced cultivars have been examined, and hundreds of unique cultivars have been newly developed. This section introduces the history of apple cultivars and breeding in Japan.

\section{Apple production in Japan}

Commercial apple production in Japan started in the 1870s using cultivars introduced mainly from the United States. By the 1900s, about 300 cultivars had been introduced from the USA, France, Canada, and other western countries, and seven cultivars, 'American Summer Pearmain', 'Ben Davis', 'Fameuse', 'Jonathan', 'Smith Cider', 'Ralls Janet', and 'Red Astrachan' had become dominant in the Japanese apple industry. During the period between 1940 and 1960, two cultivars, 'Jonathan' and 'Ralls Janet', accounted for over $85 \%$ of the total annual apple production in Japan. These old cultivars were then rapidly replaced by newly introduced cultivars such as 'Delicious' and 'Golden Delicious', and later by cultivars originally developed in Japan (Table 1, Fig. 1). In 2014, 'Fuji', 'Tsugaru',
'Orin', and 'Jonagold', accounted for 53.5\%, 11.2\%, 7.4\%, and $6.9 \%$, respectively, of the 816,300 tons of apples produced in Japan. Most of the remaining 21\% consisted of new and old cultivars developed in Japan, each constituting less than $1 \%$ or a few percent of total apple production.

\section{Apple cultivars and breeding programs in Japan}

'Indo' is believed to be the first Japanese apple cultivar, having been found as a chance seedling of 'White Winter Pearmain' in 1884. Apple breeding by systematic crossing was initiated in the early 1900s in Japan, and subsequently many cultivars were developed through government-funded breeding programs at both national and local levels, and by universities and the private sector including growers and nurseries. According to the Japan plant registration website (http://www.hinsyu.maff.go.jp/en/en_top.html), 185 original apple cultivars have been registered since 1981. Including cultivars that were registered prior to 1980 , those currently being assessed, and those commercialized without registration, our estimation for the number of Japanese cultivars is close to 300. Some of these are listed in Table 1.

The Aomori Apple Experiment Station, currently the Apple Research Institute, began apple breeding in 1928, and has registered 19 cultivars, and released 25 cultivars without registration. 'Mutsu' registered in 1949, known as 'Crispin' in the US, was the first apple cultivar to be registered in Japan. 'Tsugaru' has been the most popular early cultivar since the $1980 \mathrm{~s}$. 'Aori $27 /$ Chiyuki $^{\mathrm{TM}}$ ' is a unique nonbrowning apple developed by a crossing between 'Kinsei' and MaHe 7 (('Golden Delicious' × 'Indo') × 'Redgold'), and was patented in the USA in 2014. The flesh of the apple does not brown for more than several days after being sliced or grated, and has been shown to have low PPO activity and low polyphenol content (Kon et al. 2005, 2008, Noro et al. 2009). 'Aori 15 '/Hoshi no Kinka ${ }^{\mathrm{TM}}$ ' is a sweet and juicy yellow apple harvested in late October in Aomori, and shows remarkable storage stability over 6 months when refrigerated (Kon et al. 2012). 'Aodai 3' is a dwarf root stock with easy propagation properties.

The national Institute of Fruit Tree Science, currently the NIAS Institute of Fruit Tree Science, began apple breeding in 1939, and in 1962 registered 'Fuji', the most widely cultivated apple cultivar in Japan. This cultivar was selected from 787 seedlings derived from the cross between 'Ralls Janet' and 'Delicious'. 'Fuji' has been considered the most widely produced apple cultivar in the world (O'Rourke 2003). The fruit is juicy, sweet, crispy, and shows remarkable storage ability with no loss of firmness for at least 1 month after harvest at room temperature. A new cultivar 'Mori no Kagayaki', harvested in mid-October, is a large yellow apple with a very sweet taste and attractive aroma. 'Ruby Sweet' is a large sweet apple with red flesh, and 'Rose Pearl' is an apple with red flesh and yellow skin. 'JM 1' and 'JM 7' are dwarf root stocks with easy propagation properties.

Many other research institutes funded by local governments, including Iwate, Yamagata, Miyagi, Fukushima, 
Table 1. Cultivars originally developed in Japan

\begin{tabular}{|c|c|}
\hline $\begin{array}{l}\text { Breeding Programs } \\
\text { or Organizations }\end{array}$ & Cultivar Names (year of registration or release ${ }^{b}$ )/Trade Marks \\
\hline National & $\begin{array}{l}\text { Fuji (1962), Himekami (1985), Iwakami (1985), Sansa (1988), Kizashi (1991), JM1 }{ }^{a} \text { (1999), JM7 }{ }^{a} \text { (1999), JM8 } \\
\text { (1999), JM2 }{ }^{a} \text { (2000), JM5 }{ }^{a} \text { (2000), Kitaro (2000), Chinatsu (2001), Koutaro (2001), Santaro (2003), Hoiku Indo } \\
\text { (2007), Mori no Kagayaki (2011), Ruby Sweet (2015), Rose Pearl (2015) }\end{array}$ \\
\hline Hokkaido & Empire (1964b), HAC Nine (1986), North Queen (1989), Maoi (2004) \\
\hline Aomori pref. & 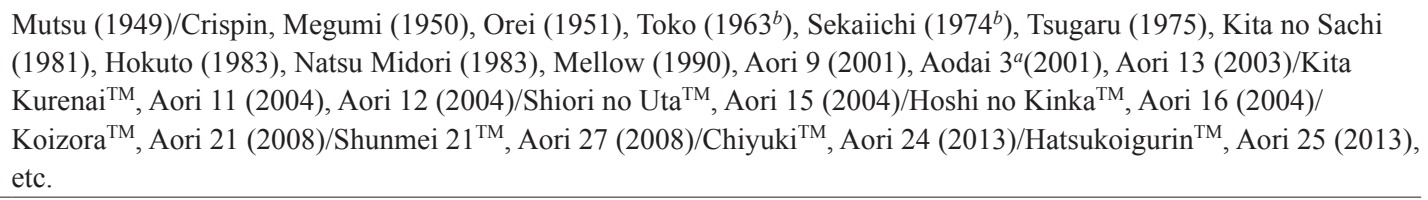 \\
\hline Akita pref. & $\begin{array}{l}\text { Senshu (1980), Akita Gold (1992), Akita Beni Akari (2005), Aki Shizuku (2007), Yume Akari (2007), Akita Beni } \\
\text { Hoppe (2009) }\end{array}$ \\
\hline Iwate pref. & Kiou (1994), Ouka (2006), Iwate 7 go (2009)/Beni Iwate ${ }^{\mathrm{TM}}$, Ooyume (2013) \\
\hline Yamagata pref. & Syuyou (2008), First Lady (2009) \\
\hline Miyagi pref. & Sour Rouge (2011) \\
\hline Fukushima pref. & Hoozuri (1996), Hi no Azuma (2006) \\
\hline Gunma pref. & $\begin{array}{l}\text { Akagi }\left(1973^{b}\right) \text {, Youkou (1981), Shin Sekai (1998), Gunma Meigetsu (1991), Slim Red (1995), Honey Queen (1995), } \\
\text { Oze no Kurenai (2009) }\end{array}$ \\
\hline Nagano pref. & $\begin{array}{l}\text { Takane (1984), Shinano Sweet (1996), Shinano Red (1997), Shinano Gold (1999), Shinano Dolce (2005), Shinano } \\
\text { Piccolo (2006), Shinano Petit (2010), Shinano Hoppe (2013) }\end{array}$ \\
\hline Ishikawa pref. & Syusei (2005) \\
\hline Regional $^{d}$ & Goshogawara (1996), Kuroishi 1 go (2006) \\
\hline Universities & Koukou (1999), Haruka (2002), Kurenai no Yume (2010), Hirodai Misaki (2010) \\
\hline Private Sectors ${ }^{e}$ & $\begin{array}{l}\text { Orin }\left(1952^{b}\right) \text {, Kinsei (1972), New Jonagold }\left(1980^{b}\right) \text {, Yataka (1987), Seirin (1990), Miki Life (1992), Akibae (1993), } \\
\text { Beni Shogun (1993), Seimei (1995), Akiyo (1996), Ryoka no Kisetsu (1999), Gold Farm (2000), Aika no Kaori (2001), } \\
\text { Toki (2004), Daikouei (2005), Takano } 1 \text { go (2010)/Beni Roman }{ }^{\mathrm{TM}} \text {, Takano } 2 \text { go (2010)/Gold Roman }{ }^{\mathrm{TM}} \text {, Takano } 3 \text { go } \\
(2010) / \text { Fujiwara Roman }{ }^{\mathrm{TM}} \text {, etc. }\end{array}$ \\
\hline \multicolumn{2}{|c|}{$\begin{array}{l}{ }^{a} \text { root stock cultivars. } \\
{ }^{b} \text { cultivars released without registration and listed with the year of public release. } \\
c \text { cultivars developed in corroboration with a national institute. } \\
{ }^{d} \text { regional government. } \\
\text { e growers and nurseries. } \\
\text { pref. = prefecture. }\end{array}$} \\
\hline
\end{tabular}

Gunma, Nagano, and Ishikawa have also developed original apple cultivars from individual breeding programs. 'Kiou', a yellow apple developed by the Iwate Agricultural Research Center, has become a very popular early cultivar that is widely cultivated in both Iwate and Aomori prefectures. 'Shinano Sweet' and 'Shinano Gold', developed by the Nagano Fruit Tree Experiment Station, are now becoming very popular, and their production is increasing, gradually replacing the established cultivars. 'Shinano Sweet' is a red sweet apple harvested between the seasons for 'Tsugaru' and 'Fuji', and has excellent eating quality. 'Shinano Gold' is a late yellow cultivar with a juicy texture and good taste, with a nice sugar and acid balance, and very good storage ability.

The private sectors, including growers and nurseries, have also developed many cultivars. Among Japanese apple cultivars, 'Orin', released in 1952, has grown to become the top-ranking yellow cultivar and the second-ranking late cultivar. 'Toki', released several years prior to its registration in 2004, is a juicy and very sweet yellow cultivar whose production is rapidly increasing.

Japan has been mostly self-sufficient in the development and utilization of apple cultivars as well as in the production and consumption of apples.

\section{DNA markers and genomic information}

The development of molecular markers and chromosome maps facilitates the location of genes responsible for important agronomic traits, and helps the breeding process through MAS. Any individual trait may be related to a major gene or several genes distributed in multiple chromosomal regions as quantitative trait loci (QTLs). Markers linked to specific traits, such as disease resistance, fruit quality, and growth habit, have been developed (reviewed by Gardiner et al. 2007, Keller-Przybyłkowicz and Korbin 2013, Marić et al. 2010, Pereira-Lorenzo et al. 2009). These markers are expected to provide solutions to several problems of fruit tree breeding such as the lengthy tree juvenile period and the large field space required for growing populations. 

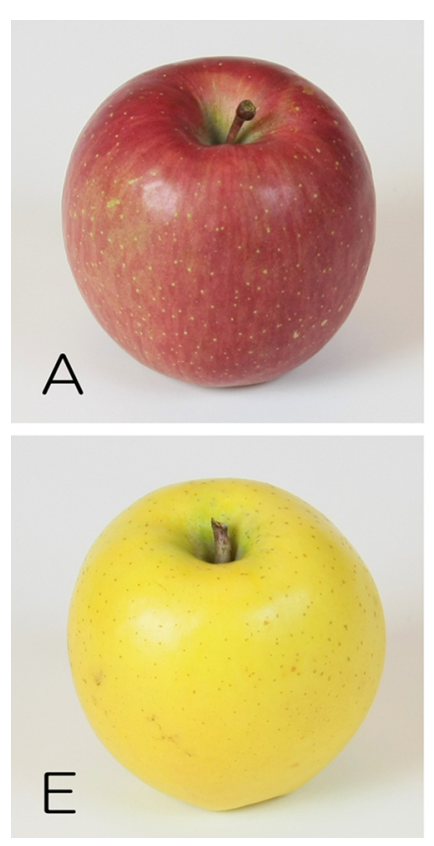
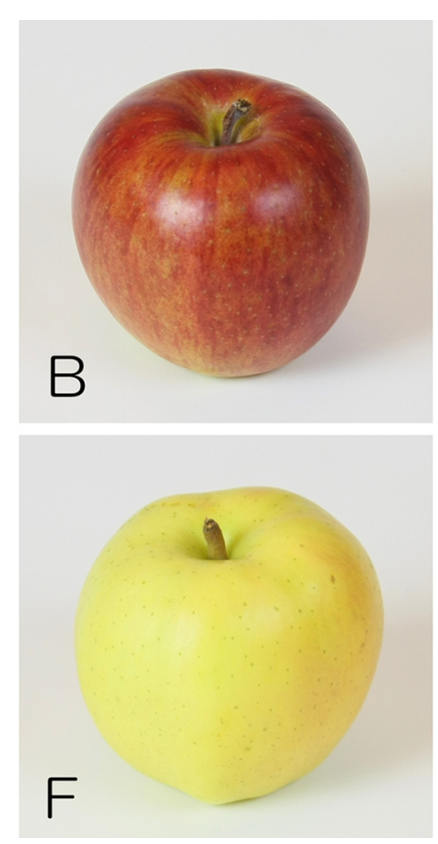
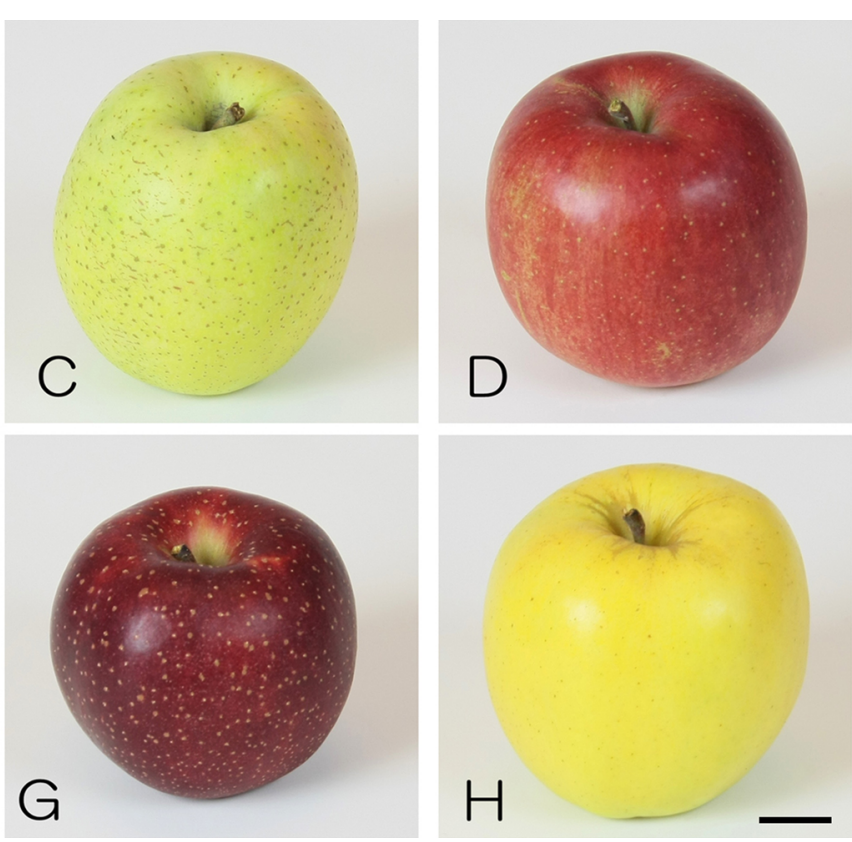

Fig. 1. Some of the apple cultivars developed in Japan. The cultivars dominating the current apple market are (A) 'Fuji' registered in 1962 , (B) 'Tsugaru' registered in 1975, (C) 'Orin' released in 1952, and the promising new cultivars are (D) 'Shinano Sweet' registered in 1996, (E) 'Shinano Gold' registered in 1999, (F) 'Toki' registered in 2004, (G) 'Aori 27/Chiyuki ${ }^{\mathrm{TM}}$ ' registered in 2008, and (H) 'Mori no Kagayaki' registered in 2011. Scale bar represents $2 \mathrm{~cm}$.

\section{Disease resistance}

In apple, scab, powdery mildew (caused by the fungal pathogen Podosphaera leucotricha), and fire blight (caused by Erwinia amylovora) are the major diseases affecting commercial apple production in many countries. For breeding of resistant apple cultivars, genes and QTLs related to disease resistance, and the linked DNA markers, have been successively identified.

Development of DNA markers for scab resistance has preceded that of markers for other diseases. Seventeen genes for apple scab resistance have been identified, and their global positions have been located on the apple genetic map (Bus et al. 2011). Among them, the most intensively studied has been the Rvi6 (Vf) gene from M. floribunda 821 . This was the first fine-mapped scab resistance gene, and defined as a receptor-like gene showing homology to candidate tomato genes for Cladosporium fulvum resistance (Vinatzer et al. 2001). The Rvil5 ( $V r 2)$ locus was found to contain three candidate genes (of the Toll and mammalian interleukin-1 receptor protein nucleotide-binding site leucine-rich repeat structure resistance gene family) (Galli et al. 2010a, 2010b, Schouten et al. 2014), and the Rvil $(\mathrm{Vg})$ locus was shown to contain 6 ORFs of four putative TIR-NBS-LRR (TNL) genes, a TNL pseudogene, and a serine/threonine protein phosphatase 2A gene (Cova et al. 2015). Furthermore, Soriano et al. (2014) have developed SSR markers linked to the broad-spectrum resistance of the selection 1980-015-025 (V25), and fine-mapped them on LG11 as Rvi18. This region contains a lectin-like receptor kinase (LRK) as a candidate gene for resistance. Clark et al.
(2014) have also identified two novel scab resistance loci in 'Honeycrisp', and mapped the loci as Rvi19 and Rvi20 on LG1 and LG15, respectively. They suggest that genes containing a leucine rich repeat region (LRR), a motif common in $\mathrm{R}$ genes, would be the prime candidate at each locus. Bastiaanse et al. (2015) have reported that resistance in 'Geneva' is conditioned by at least five NBS-LRR candidate genes clustered on LG4. Padmarasu et al. (2014) have mapped Rvi12 ( Vb) on LG12 of Malus baccata Hansen's baccata \#2, and developed 16 SNP markers for resistance selection. Among the identified scab-resistance genes, Rvil5 $(V r 2)$ and Rvi6 ( $V f)$ have been proven to be practical for transformation of common susceptible cultivars ( $\operatorname{Vr} 2$ : Shouten et al. 2014, Vf: Belfanti et al. 2004, Joshi et al. 2011, Würdig et al. 2015).

Many apple cultivars with the Rvi6 ( $V f)$ gene have been developed by MAS, and are now in commercial use. In Japan, a scab-resistant cultivar 'Aori 25' has been developed, and the presence of the Rvi6 ( $V f)$ gene has been identified on the basis of DNA markers (Kudo et al. 2013). However, as breakdown of resistance conferred by a single gene has been observed at several experimental farms (Bénaouf and Parisi 2000, Parisi et al. 2006), accumulation of multiple resistance genes has become an essential strategy.

Although each of the developed molecular markers is a powerful tool for the pyramiding of resistance genes, it is necessary to include reference cultivars or strains derived from original studies for the appropriate use of such markers. Patocchi et al. (2009) standardized SSR markers linked to nine scab resistance genes (Rvi2, Rvi4, Rvi5, Rvi6, Rvil1, 
Rvi12, Rvi13, Rvi14, and Rvi15) by sizing the alleles of four cultivars ('Fiesta', 'Prima', 'Gala', 'Golden Delicious'). These markers make it possible to breed durable scabresistant cultivars through the pyramiding of resistant genes.

With regard to powdery mildew resistance, DNA markers have been reported for five major genes, $P l 1$ on LG12, Pl2 on LG11, Plw on LG8, Pld on LG12, and Plmis on LG11 (Dunemann et al. 2007, Fernández-Fernández et al. 2008, Gardiner et al. 2003, 2004, James et al. 2004, James and Evans 2004, Rikkerink et al. 2010). Calenge and Durel (2006) analyzed QTLs in F1 progenies (Discovery and TN10-8) over a four-year period (five seasons), and detected seven QTLs. They reported that the QTL regions on LG2 included most members of a RGA cluster, and that the QTL on LG8 was located $2 \sim 4.3 \mathrm{cM}$ from $P l w$ derived from 'White Angel'. The QTL on LG8 exhibited a major effect whereas QTLs on LG2 and LG13 exhibited intermediate but stable effects over the five seasons. These results suggest that a combination of these QTLs, the major effect QTL and the stable QTLs, would be required in order to obtain sufficient resistance to powdery mildew.

Khan et al. (2006) have identified a major QTL for fireblight resistance on LG7 in the apple cultivar 'Fiesta'. From this QTL, a SCAR marker suitable for MAS was also developed (Khan et al. 2007). An ornamental cv.'Evereste' exhibited a strong QTL effect of the resistance on LG12 (Durel et al. 2009). Within the QTL interval, a $189 \mathrm{~kb}$ sequence was identified and cloned, on which new microsatellite markers were developed (Parravicini et al. 2011). The annotation of genetic elements contained in this fragment revealed the presence a cluster of eight genes, the Pto/Prf complex, showing homology to known genes conferring resistance to bacterial disease in tomato. Peil et al. (2007) mapped a major QTL on LG3 in Malus $\times$ robusta 5. By analyzing three populations derived from 'Robusta 5' accessions (Gardiner et al. 2012), three fire-blight resistance QTLs were also detected. The QTL identified on LG7, using a population grown in the USA, was co-located with a heat shock 90 family protein gene (HSP90) and a WRKY transcription factor gene. Analysis carried out on a population grown in Germany instead allowed the identification of a QTL on LG3, co-located with another HSP90. Finally, a QTL identified on LG3 was also discovered in New Zealand, which was co-located with a leucine-rich repeat family receptorlike protein gene (MxdRLP1).

Khan et al. (2012) reported information (linkage groups, closest marker, marker type etc.) for 27 QTLs obtained in individual studies using different genetic backgrounds and strains, and presented a scheme for breeding fire-blight resistant cultivars by utilizing three strong stable QTLs (LG3/Malus $\times$ robusta 5, LG12/M. floribunda clone 821, 'Evereste', LG7/'Fiesta'). Khan et al. (2013) then identified additional QTLs on LG2, LG6 and LG15 and a total of 34 significant associations for resistance to fire blight through a genome wide association study (GWAS). Within the QTL region on LG3 of Malus $\times$ robusta 5, a candidate resistance gene Fb_MR5, which belongs to the CC-NBS-LRR resistance gene family, was detected (Fahrentrapp et al. 2013). It was suggested that this gene was a determinant of resistance because transgenic 'Gala' showed significantly less severe fire blight symptoms (Broggini et al. 2014).

The development of new varieties with multiple disease resistance and high fruit quality has become a major goal in many apple breeding programs. For this purpose, MAS would be a highly effective approach. Kellerhals et al. (2008) reported the selection of multi-disease resistant seedlings by pyramiding two scab resistance genes (Rvi6 ( Vf) and Rvi2 (Vh2) or Rvi4 (Vh4)) and a mildew resistance gene (Pll or Pl2) using DNA markers specific to each of the genes. They also attempted to construct a MAS system combining the QTLs for fire blight resistance with scab resistance.

Jänsch et al. (2015) developed SNPs linked to eight disease resistance genes (scab: Rvi2, Rvi 4, Rvi 6, Rvi 11, Rvi 15, powdery mildew: $P l 2$, fire blight: $F B E, F B M R 5$ ), and refined the locus of Rvi2, Rvi4, and Rvi11. They then validated specificity of their alleles in coupling with resistance by determining the allele composition in eight apple genotypes ('Golden Delicious', 'Delicious', 'Cox's Orange Pippin', 'Jonathan, McIntosh', 'Granny Smith', 'Braeburn', and selection F2-26829-2-2 derived from M. floribunda 821 ) by systematic high throughput analysis in markerassisted breeding (MAB). Baumgartner et al. (2015) bred valuable homozygous lines as breeding parents for pyramiding of resistance genes using markers of the resistance genes or QTLs for scab (Rvi2, Rvi4, Rvi6), powdery mildew (Pl1, Pl2) and fire blight (FBF7).

Although the occurrence of fire-blight has not yet been reported in Japan, Alternaria leaf-blotch has been the most problematic disease for apple growers and researchers since the 1960s. Based on detailed genetic analyses of F1 populations derived from crosses between cultivars, Saito and Takeda (1984) reported that susceptibility to Alternaria blotch was determined by a major gene $($ Alt $)$, and was a dominantly inherited trait. Fukasawa-Akada et al. (1999, 2000a, 2000b, 2003) identified RAPD markers linked to the susceptibility of 'Kaori', an offspring of 'Delicious'. By analyzing 108 cultivars and strains, they demonstrated a strong correlation between the susceptible phenotype and the presence of the markers, tracing their origin back to the cultivars 'Delicious' and 'Indo'. Moriya et al. (2011) mapped Alt between two SSRs at the upper end of LG11 of 'Starking Delicious', and defined DR033892 as the nearest marker (Moriya et al. 2013). They also developed a MAS system for apple seedlings with these SSRs linked to Alternaria blotch resistance and fruit skin color (Moriya et al. 2012b). Later, Moriya et al. (2013) narrowed the region to $102 \mathrm{~kb}$ (containing ten candidate genes) using 32 newly developed SSR markers. Tabira and Otani (2004) validated the use of SNP in the alpha subunit of the chloroplast chaperonin (cpn-alpha) gene in a system for selection of seedlings resistant to Alternaria blotch (Japan Patent Kokai 
2004-283002). However, Okada et al. (2011) reported that cpn-alpha is linked to Alt, but not Alt itself. Abe et al. (2012a, 2012b) studied the inheritance of moderate susceptibility in 'Sekai-ichi', 'Golden Delicious' and 'Orin', and suggested the presence of a dominant gene (Alt-2), different from Alt, that was common among the cultivars. However, Moriya et al. (2012a) mapped the QTL for moderate susceptibility on Orin LG11, in the same region of Alt. It is not yet clear whether Alt and Alt-2 are the same loci. On the other hand, there is a report that SSR on other LGs was linked to the susceptibility of 'Golden Delicious' (Li et al. 2011).

Crown gall is also a serious disease affecting Japanese apple production, caused by Agrobacterium tumefaciens. The Japanese wild apple Malus sieboldii Sanashi 63 is reported to carry the crown gall resistance gene $\mathrm{Cg}$, against the strain Peach CG8331, and has been identified as a crown gall-resistant rootstock (Moriya et al. 2008). Moriya et al. (2010) mapped Cg to LG 2 of the wild apple, and developed selectable markers for MAS.

\section{Fruit quality}

Improvement of fruit quality and growth habit is also a major goal of apple breeding programs worldwide. Many important fruit quality traits are regulated by multiple genes, and thus more information about the QTLs for these traits is required for MAS. Since the previous reviews (Gadiner et al. 2007, Keller-Przybyłkowicz and Korbin 2013, Marić et al. 2010, Pereira-Lorenzo et al. 2009), many new molecular markers related to fruit characteristics have been reported. The relevant reports are listed in Table 2.

Most of the QTL analyses reported so far have been performed using populations derived from cultivars ('Prima', 'Fiesta', 'Discovery', 'Telamon' etc.) developed in Europe, the USA, or New Zealand. Apple breeding programs in Japan have been performed using cultivars and strains with a rather unique genetic background, and thus evaluating the effects of genetic background has become important. Kunihisa et al. (2014) analyzed QTLs for 16 traits using a Japanese cultivar F1 population ('Orin' originated from 'Indo' $\times$ 'Golden Delicious', yellow fruit skin cultivar, $\times$ 'Akane' from 'Jonathan' $\times$ 'Worcester Pearmain', scab resistant). They identified QTLs that overlapped those reported previously for foreign cultivars, and also detected novel QTLs for harvest time, Brix, flowering date and juice browning. Among four QTLs for harvest time, a novel one was detected near the locus of the MdACS1 gene on LG15 of 'Orin'. Examining relationships among the directions of the allelic effects of linked QTLs, they also demonstrated that the allele for early ripening and the ACS1-1 allele for fruit drop were in a coupling phase on LG15, and that the effects of two QTLs (harvest time and firmness) on 'Akane' LG3 for earlier ripening and softer flesh were also similar. They investigated the actual validity of MAS using QTL markers by evaluating the broad-sense heritability of each trait, and concluded that these four QTLs (detected in LG3, 10,15 and 16) can be used on a practical level for MAS of harvest time as well as for acidity based on the QTLs in LG8 and LG16. Their reports indicated two QTLs for depth of fruit skin color, one located close to the locus of the MdMYB1 gene responsible for apple skin color at the lower end of LG9, and the other located on the hot spot for QTLs related to polyphenolic compounds of LG16. These results are important for breeding of Japanese apple cultivars, because fruit appearance is an important factor for consumers in Japan.

With regard to other traits related to the economically important aspects of fruit appearance, such as bitter pit, skin russeting, and fruit size, many reports have identified related QTL regions and candidate genes (Buti et al. 2015, Chang et al. 2014, Devoghalaere et al. 2012, Falginella et al. 2015, Kunihisa et al. 2014, Potts et al. 2014, Sun et al. 2015), as well as those for other fruit quality traits such as fruit texture (Chagné et al. 2014, Kunihisa et al. 2014, Longhi et al. 2012, 2013a, 2013b, Sun et al. 2015), ingredients (Bai et al. 2012b, Guan et al. 2015, Kunihisa et al. 2014, Morimoto et al. 2014, Potts et al. 2014, Sun et al. 2015) and tree habit (Bai et al. 2012a, Celton et al. 2014, Guitton et al. 2012, Morimoto and Banno 2015, Moriya et al. 2012c, 2015). Among them, firmness is a trait important for the texture and storage of fruit, and therefore a number of related QTLs have been identified (Chagné et al. 2014, Kunihisa et al. 2014, Marondedze and Thomas 2013, Sun et al. 2015). Costa et al. (2010) have already mapped Md-PG1 to a locus of LG 10, within the QTL region associated with fruit firmness. Three haplotypes of the $M d-P G 1$ marker have been validated as selectable for fruit firmness (Longhi et al. 2013b), and a SNP marker (PG_FEM_LC_19) of Md-PG1 has been used for MAS in the FruitBreedomics program.

\section{Advanced technology}

Since any given locus captures only a small proportion of the total genetic variance for complex traits, a large number of genome-wide markers are required for making accurate selection decisions. A project involving eleven European research groups, HiDRAS (High-quality Disease Resistant Apples for Sustainable Agriculture), has been supplying molecular markers linked to fruit quality and pathogen resistance QTLs through a dedicated website (URL: http:// www.hidras.unimi.it/) to facilitate identification of the genetic factors that control fruit quality. The international RosBREED SNP consortium (IRSC, URL:www.rosbreed ORG), an American team centered at Michigan State University, has developed a total of 7867 apple SNPs (single nucleotide polymorphisms) through next-generation sequencing of 27 cultivars used as founders in global apple breeding programs. This consortium has initially developed the 8K SNP array (Chagné et al. 2012b), which is anticipated to be effective for a wide range of germplasms and applications such as high-resolution genetic mapping, QTL detection and characterization, and marker-assisted introgression.

Genomic selection (GS) can be used to obtain genomic 
Table 2. QTLs and genes reported recently in apple fruit character and growth habit

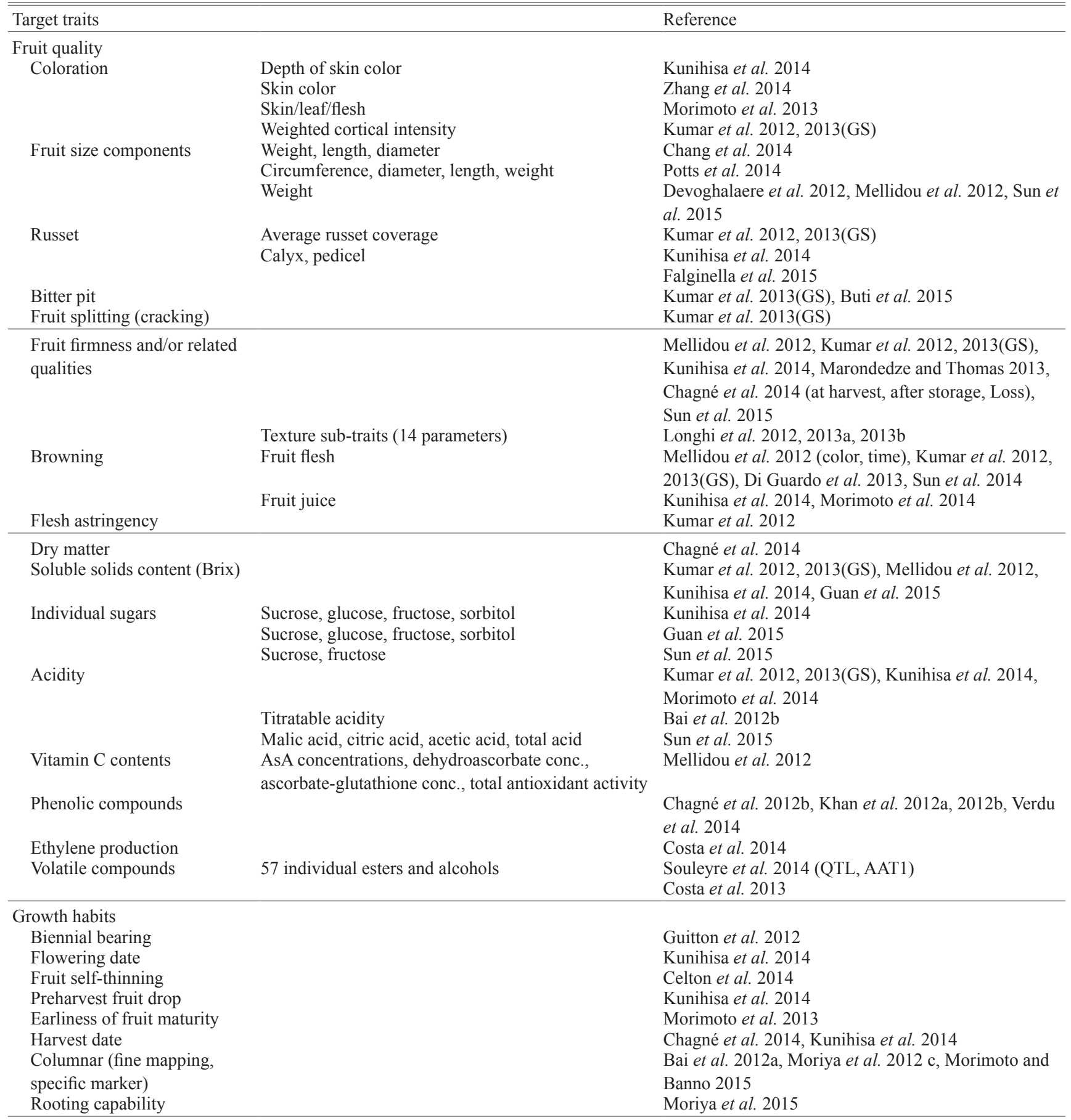

breeding values for selection of next-generation parents or potential cultivars for further testing at a very early stage (Desta and Ortiz 2014). By using an 8K SNP array and a population of 1,200 seedlings, Kumar et al. (2012) evaluated the accuracy of GS, and demonstrated its suitability as an alternative approach for fruit trait selection. Furthermore, Bianco et al. (2014) have developed a more high-throughput whole-genome genotyping array $(20 \mathrm{~K})$ for apple.

Most of the QTL analyses reported so far have involved one or two crossing populations. For practical use of QTL markers among different genetic backgrounds, Costa (2015) performed MetaQTL analysis using four populations from six parental lines, 1,289 SNP genotypes and phenotypes for fruit quality traits, and incorporated the most relevant QTLs associated with important fruit quality traits into a consensus map. He suggested that this method would become more powerful for identification of candidate genes controlling relevant fruit quality traits through improvement 
with additional pedigreed families and genotyping tools facilitating a higher marker density.

In 2011, the FruitBreedomics Project, an international consortium composed of 18 research institutes from Europe, Israel, South Africa, New Zealand and China and 6 small to medium enterprises, was launched to improve the efficiency of fruit breeding by bridging the gap between genomics and breeding (http://www.fruitbreedomics.com/, Laurens et al. 2010). The project ended on August 31st, 2015 with the generation of new tools for phenotyping, genotyping and transcriptomics such as ASSIsT, an automatic SNP scoring tool for the selection of high-quality reliable markers (Di Guardo et al. 2015).

\section{Transgenic technology}

Twenty years have passed since the first gene modified (GM) crop (Flavor Savor tomato) was commercialized in 1994 (Kramer and Redenbaugh 1994). Cultivation of GM crops has continued to increase steadily and globally over the past few years, and at present, over 15 GM crops are being cultivated in about 25 countries. There is now general scientific agreement that food derived from GM crops poses no greater risk to human health than crops bred using conventional techniques. Recently, the world's first GM apple, which does not turn brown when cut or bruised, was approved for consumption by the United States Department of Agriculture (Xu 2013). However, GM cultivation itself has not yet been introduced in several countries including Japan, mainly because of general public skepticism about the safety of GM crops. On the other hand, transgenic apple trees have been created experimentally to investigate the applicability of GM technology. This section introduces the development of the GM apple for breeding systems using transgenic techniques.

\section{Root stock improvement}

In early transgenic studies of apple, the rol genes isolated from Agrobacterium rhizogenes were used to improve the rooting ability of the M.26 and M.9, dwarf root stocks. These root stocks are propagated vegetatively, but are often difficult to root. To improve their rooting ability, transgenic technology has been applied using the rol genes, which are plant oncogenes carried in the Ri plasmids of $A$. rhizogenes (Lambert and Tepfer 1992). Rol genes induce not only enhancement of rooting initiation, but also a dwarfing character. Therefore, they have also been used to induce dwarfing in wild-type rootstock (Holefors et al. 1998, Welander et al. 1998, Zhu et al. 2001a, 2001b). In Japan, Igarashi et al. (2002) incorporated the rolC gene into the most popular rootstock in Japan, 'Marubakaidou' (M. prunifolia), which has high rooting ability but no dwarf character. The transgenic Marubakaidou exhibited a dwarfing trait with a reduction of internode length. Furthermore, these transgenic lines showed enhanced rooting ability. However, development of the transgenic apple was suspended because it proved diffi- cult to obtain public understanding of GM apple production in Japan, and thus accurate greenhouse evaluation of the trait could not be performed.

\section{Fruit improvement}

Research aimed at improvement of apple fruit has focused mainly on storage quality and shelf-life. In Japan, Wakasa et al. (2006) reported that cultivars retaining firm flesh during storage showed very weak or transient expression of an endo-polygalacturonase (MdPG1), irrespective of the ethylene production rate and transcription levels of other ripening-related genes. These results strongly suggested that softening during ripening may depend on the expression pattern of $M d P G 1$. Indeed, $M d P G 1$-suppressed 'Royal Gala' apples harvested at various seasons were firmer than controls after ripening (Atkinson et al. 2012).

Apple flesh turns brown after being sliced or grated, due to a phenolic polymer produced by polyphenol oxidases (PPOs) (Murata et al. 2000). Although browning is a natural phenomenon, it is usually an undesirable feature for consumers. A company in Canada (Okanagan Specialty Fruits Inc.) has genetically modified 'Granny Smith' and 'Golden Delicious' by inhibiting four $M d P P O$ genes using the RNAi approach. The resulting transgenic line showed a strong reduction of the browning process compared with the control. This GM apple showed a $90 \%$ reduction of the enzyme activity in mature fruit. The decision to deregulate these GM apple varieties was announced by the USDA Animal and Plant Health Inspection Service in February 2015. However, this GM apple genome retains a selectable marker gene for kanamycin resistance (Carter 2012). Therefore, it may not easy to convince consumers about the acceptability of this GM apple.

\section{Disease resistance}

The most serious diseases that hamper apple cultivation are scab and fire blight. Over the last few decades, apple varieties have been bred for production of better resistance. For more than half a century (1914 to 1970), the scab resistance gene Rvi6/Vf, originating from the wild species Malus floribunda 821, was incorporated into a wide variety of apple cultivars through crossing. However, the creation of a variety possessing the $V f$ resistance gene, but with commercially sufficient fruit quality, was not easy (Dayton et al. 1970). In order to improve the scab resistance of apples, genes encoding chitinolytic enzymes from a bio-control organism Trichoderma harzianum were introduced into apple (Bolar et al. 2000, 2001). The resulting transgenic lines expressing the genes were more resistant than nontransformed controls. Analysis of the $V f$ region led to the identification of a cluster of genes homologos to the tomato Cladosporium fulvum resistance gene family (Vinatzer et al. 2001). One of these genes, HcrVf2, was used to transform the susceptible apple cultivar 'Gala'(Belfanti et al. 2004).

As a candidate gene conferring resistance to fire blight disease, the attacin $\mathrm{E}$ gene derived from Hyalophora 
cecropia (the North America silkworm moth) has been used. Attacin E exhibits substantial lytic activity against many important plant pathogenic bacteria, and apple trees transformed with this gene exhibited resistance to fire blight (Borejsza-Wysocka et al. 2010, Ko et al. 2002). Apples incorporating the $L c$ gene, a bHLH transcription factor of maize, exhibited resistance to both scab and fire blight ( $\mathrm{Li}$ et al. 2007). It is considered that the effect is likely related to enhancement of biosynthesis of a specific flavonoid, which plays important roles in the plant response to pathogens. Moreover, Krens et al. (2011) have reported that transgenic apple lines carrying the barley hordothionin gene (hth), which inhibits in vitro growth of a number of fungi and bacteria (Terras et al. 1993), were significantly less susceptible to scab disease.

\section{Cisgenesis and marker free}

Public concern about the suggested or perceived risks of GM crops centers mainly around the presence of foreign gene(s) in the genome. To circumvent this issue, cisgenesis technology has been implemented. Cisgenesis uses all parts of the transgenes including the promoter and terminator, derived from sexually compatible plants (Holme et al. 2013). Furthermore, it has become possible to delete transformed selection markers, such as antibiotic resistance genes, using recombinase systems. These techniques have been utilized in some transgenic apples (Joshi et al. 2011, Krens et al. 2015, Schaart et al. 2011b, Vanblaere et al. 2014, Würdig et al. 2015). On the other hand, genetic transformation in apple has been achieved without the use of a selectable marker gene (Krens et al. 2015, Malnoy et al. 2010)

\section{Early flowering}

Apple trees have a long juvenile phase of 5-12 years or more, during which young seedlings cannot be induced to flower. This places a constraint on genetic analysis and the creation of new apple cultivars through cross-breeding. When seedlings are obtained from crosses with wild apple species, an even longer period is needed. Studies of a model plant, Arabidopsis thaliana, have identified several flowering-related genes during the last fifteen years. Apple homologues of the Arabidopsis TFL1 and FT genes have been identified in Japan, and up-regulation of the MdFT gene in apple has resulted in precocious flowering (Kotoda et al. 2010). On the other hand, Flachowsky et al. (2007) have succeeded in breaking the juvenile phase through overexpression of the BpMADS4 gene of silver birch (Betula pendula). The resulting transgenic apples came into flower only 3 to 4 months after planting in a glass house. The transgenic line was crossed with a fire blight-resistant wild species, and the resulting F1 seedlings were selected for BpMADS4 and fire blight resistance, then backcrossed with another cultivar to integrate the scab resistance gene (Flachowsky et al. 2011, Le Roux et al. 2012). Recently, BpMADS4 has been integrated into various linkage groups of four different apple cultivars (Weigl et al. 2015) with the intention of selecting non-transgenic null segregates at the end of the breeding program. Another outstanding technique for shortening the generation period of apple seedlings using a plant virus vector (Yamagishi et al. 2014) will be described in the following section.

\section{New plant breeding technology}

Although, transgene technology has provided opportunities to go beyond natural crossing barriers, it has also raised questions about possible effects on human health and the environment. In 2000, the Cartagena Protocol on Bio-safety was adopted at the Convention on Biological Diversity, and almost all countries have signed up to gene modified organism (GMO) legislation. Consequently, approval for introducing a GM crop to the market has become a very expensive issue, as documents pertaining to experimental safety verification must be submitted (Hartung et al. 2014). Thus, development has been preferentially focused on major crops such as soybean and maize (Heap 2013), whereas that of minor crops, such as fruit trees and apple, has been greatly delayed. Another reason for the delay is that development and evaluation of GM fruit trees requires a long period in comparison with annual crops. In the early 2010 s, new plant breeding techniques (NPBT; Lusser et al. 2012) have emerged. Here, some of them that are closely applicable to apple breeding are introduced.

\section{Trans-grafting}

Grafting is a cultivation method that exploits the cooperative relationship between partner plants possessing different genomes (Mudge et al. 2009). In apple cultivation, it has been used mainly for maintenance and propagation of clone strains, and for altering plant vigor, architecture, and precocity. Since the rootstock interacts with soil, it greatly affects the growth and production ability of the scion through water and mineral uptake. Trans-grafting refers to grafting a GM part with a non-GM part. The GM-root provides the potential of using transgenic rootstocks to improve the performance of commercially approved scion varieties, and produce non-GM products. Therefore, trans-grafted plants have the potential to address the public's concerns about transgene flow and exogenous transgene products in most transgenic organisms. As a matter of course, GM parts can be used for cisgenic (genetic modification by disusing a non-crossable species or a synthetic gene) strategies (Lusser et al. 2012). In the scion on rolB-induced rootstock, no rolB gene was detected by PCR analysis, suggesting that the transgene was not translocated from rootstock to scion (Smolka et al. 2010).

Hetero-grafting experiments using herbaceous plants, such as tomato and pumpkin, have revealed that specific mRNAs, such as GAI (GIBBERELLIC ACID INSENSITIVE), are capable of long-distance transport in phloem (Haywood et al. 2005), as well as viral RNA and viroids. 
Furthermore, recent studies using deep sequencing techniques have disclosed that over 2000 transcripts are translocated between shoots and roots in Arabidopsis (Thieme et al. 2015) and grapevines (Yang et al. 2015). It has been considered that in apple, as a representative woody plant, the same RNA transportability would be observed. In fact, Kanehira et al. (2010) in Japan have shown that phloem cells obtained by laser-capture micro-dissection from sub-cultured apple shoots harbor mRNAs that have already been reported as phloem-transported RNAs in other plants. Furthermore, they have confirmed that transport of GAI mRNA between 'Fuji' and a root stock occurs in 3-year-old shoots in both upward and downward directions via the graft union (Xu et al. 2010). It has also been demonstrated that gai transgenic Marubakaidou rootstock conferred a dwarf phenotype to the 'Orin' scion and lower sensitivity to GA enhancement of stature ( $\mathrm{Xu}$ et al. 2013). Thus, the trans-grafting system has the potential to improve the scion through transport of a specific gene mRNA from the GMstock (Harada 2010).

Small RNAs have also been shown to be transportable in phloem. Flachowsky et al. (2012) reported that small RNAs can be transported through the graft union to apple subcultured shoots. In sweet cherry, Zhao and Song (2014) have confirmed long-distance $(1.2 \mathrm{~m})$ transfer of siRNA targeting the plum necrotic ringspot virus (PNRSV-hpRNA) from a transgenic rootstock to a non-transgenic scion. They also demonstrated that the transferred siRNAs enhanced the virus resistance of scions grafted on the GM stock. Therefore, trans-grafting technology to achieve transport of siRNA would provide an opportunity for apple improvement Kasai et al. (2011) and Bai et al. (2011) in Japan using tobacco plants have demonstrated that small RNA transported through the graft-union induce not only post-transcriptional gene silencing (PTGS) but also transcriptional gene silencing (TGS) of the target gene in the grafted partner. Thus, the combination of small RNA and grafting may allow the creation of innovative approaches for improvement of fruit crops (Kasai and Harada 2015).

\section{ALSV vector}

Viral vectors are a tool commonly used by molecular biologists to deliver genetic material into cells (Vainstein et al. 2011). This is the most effective means of gene transfer because of the ease of infection and the high degree of gene expression through spontaneous propagation of virus molecules in the cell. Furthermore, there is no need for tissue culture. Apple latent spherical virus (ALSV) is an ideal virus for this purpose because it produces no disease symptoms, and vertical transmission occurring via seed is extremely low (Nakamura et al. 2011). In addition, as horizontal transmission of ALSV via pollen does not occur among apple trees in an orchard (Nakamura et al. 2011), this vector is easy to manage safely in terms of bio-containment.

Yamagishi et al. (2011) in Japan have successfully induced rapid flowering in apple seedlings using the ALSV vector expressing the AtFT gene. Moreover, Yamagishi et al. (2014) have reported a novel technique that simultaneously promotes expression of the AtFT gene and silencing of the apple MdTFL1-1 using the ALSV vector to greatly accelerate the flowering time and life cycle of apple seedlings. This system can reduce the time required for completion of the apple life cycle to 1 year or less. Furthermore, it was proved that all of the 47 next-generation seedlings were virus-free. Therefore, the authors claim that the successive progeny obtained using this technique would satisfy the regulations for GM organisms (Yamagishi et al. 2014).

\section{Genome and epi-genome editing}

Breeding strategies using mutations induced by irradiation or chemicals have played an important role in the development of new cultivars in fruit species. However, their effectiveness is very low, and the loci of mutations are random and not controllable. Recent biological technologies (ZFN, TALENS, CRISPR/Cas9) allow direct manipulation of target genetic sequences, leading to the desired phenotype. Since this technique, genome editing is a type of genetic engineering in which DNA is inserted, replaced, or removed from a genome using artificially engineered nucleases, legal regulations are expected to be much less stringent than for transgenic plants. Already, several countries, such as the USA and Israel, have approved plants derived by targeted mutagenesis as non-GM products. Peer et al. (2015) have reported the efficacy of ZFN technology in apple plants. Once genome editing has induced a mutation, it is desirable that the starter fragment (ZFNs gene) is not retained in the genome in order to ensure non-transgenic breeding. The authors have proposed using Agrobacteriummediated transient expression or virus inoculation techniques combined with a high-efficacy regeneration system. In particular, direct delivery of endo-nuclease into target cells by virus vectors provides a unique non-transgenic approach for the production of gene-edited apple plants (Vainstein et al. 2011). The CRISPR/Cas9 genome-editing system will soon be applied to breeding of both apple and sweet orange (Jia and Wang 2014).

Epigenetic mechanisms including histone modifications and DNA methylation are critical for accurate gene expression. In view of the long-term memory afforded by epigenome editing, it would be a novel and attractive technology for the improvement of vegetatively propagated species, because it does not involve a germplasm in which epigenetic reprogramming occurs (Crevillén et al. 2014). Although detailed epigenetic research, such as that for Arabidopsis and rice, has not been carried out for apple, many phenotypic variations in apple may be correlated with epigenetics (Telias et al. 2011). Furthermore, editing using CRISPRCas9-base acetyl transferase may be adaptable to apple breeding systems (Hilton et al. 2015). Apple varieties improved by these modern techniques are considered to be equivalent to naturally occurring sports, and development of many improved apple cultivars is expected in the near future. 


\section{Conclusions and future prospects}

Following developments in molecular biology, genomics, and bioinformatics, new breeding technologies are being developed rapidly. Traditional apple breeding involves the deliberate crossing of closely or distantly related individuals to produce new varieties with desirable properties. For such breeding, MAS is being steadily applied. Simultaneously, for improvement of existing trusted cultivars, new transgenic technologies can be applied in order to quickly eliminate any foreign genes. Furthermore, genome editing, by which only the target gene can be accurately modified, is emerging as a novel breeding technology. These new technologies will undoubtedly facilitate apple breeding, and yield novel and attractive apple cultivars.

In Japan, techniques, such as MAS, trans-grafting, and reduction of generation time by virus vectors, are being studied for practical use. On the other hand, technologies utilizing a large volume of genomic information and molecular markers, such as GS and Meta QTL, are yet to be acquired. It will also be necessary to adopt information on markers to Japanese apple cultivars, which have emerged via unique evolution. The importance of individual diseases and fruit characteristics may differ among countries, as growth conditions and consumer preference vary internationally. Development of apple cultivars that satisfy consumers and related industries will be accelerated by the integration of new genomic information, new technologies and existing breeding programs.

\section{Literature Cited}

Abe, K., S. Moriya, K. Okada, T.Haji and H. Iwanami (2012a) Inheritance of susceptibility to Alternaria blotch in 'Orin' apple. Hort. Res. (Japan) 11 (Suppl. 1): 259.

Abe, K., S. Moriya, K. Okada, H. Iwanami and T. Haji (2012b) 'Golden Delicious', 'Sekai-ichi' and 'Orin' apple possess a same dominant gene controlling moderate susceptibility against Alternaria blotch in apple. Hort. Res. (Japan) 11 (Suppl. 2): 330.

Atkinson, R.G., P.W. Sutherland, S.L. Johnston, K. Gunaseelan, I.C. Hallett, D. Mitra, D.A.Brummell, R. Schröder, J.W. Johnston and R.J. Schaffer (2012) Down-regulation of POLYGALACTURONASE1 alters firmness, tensile strength and water loss in apple (Malus $\times$ domestica) fruit. BMC Plant Biol. 12: 129.

Bai, S., A. Kasai, K. Yamada, T. Li and T. Harada (2011) Mobile signal transported over a long distance induces systemic transcriptional gene silencing in a grafted partner. J. Exp. Bot. 62: 4561-4570.

Bai,T., Y.Zhu, F. Fernández-Fernández, J.Keulemans, S. Brown and K.Xu (2012a) Fine genetic mapping of the Co locus controlling columnar growth habit in apple. Mol. Genet. Genomics 287: 437450.

Bai, Y., L. Dougherty, M.Li, G. Fazio, L.Cheng and K.Xu (2012b) A natural mutation-led truncation in one of the two aluminumactivated malate transporter-like genes at the $M a$ locus is associated with low fruit acidity in apple. Mol. Genet. Genomics 287: 663-678.

Bastiaanse,H., H.C. Bassett, C. Kirk， S.E. Gardiner， C.Deng， R. Groenworld, D.Chagné, and V.G.Bus (2015) Scab resistance in
'Geneva' apple is conditioned by a resistance gene cluster with complex genetic control. Mol. Plant Pathol. 17: 159-172.

Baumgartner,I.O., A.Patocchi, J.E.Frey, A.Peil and M.Kellerhals (2015) Breeding elite lines of apple carrying pyramided homozygous resistance genes against apple scab and resistance against powdery mildew and fire blight. Plant Mol. Biol. Rep. 33: 15731583.

Belfanti,E., E. Sifverberg-Dilworth, S. Tartarini, A.Patocchi, M. Barbieri, J.Zhu, B.A. Vinatzer, L. Gianfranceschi, C. Gessler and S. Sansavini (2004) The HcrVf2 gene from a wild apple confers scab resistance to a transgenic cultivated variety. Proc. Natl. Acad. Sci. USA 101: 886-890.

Bénaouf, G. and L. Parisi (2000) Genetics of host-pathogen relationships between Venturia inaequalis races 6 and 7 and Malus species. Phytopathology 90: 236-242.

Bianco, L., A. Cestaro, D.J. Sargent, E. Banchi, S. Derdak, M. Di Guardo, S. Salvi, J. Jansen, R. Viola, I. Gut et al. (2014) Development and validation of a $20 \mathrm{~K}$ single nucleotide polymorphism (SNP) whole genome genotyping array for apple (Malus $\times$ domestica Borkh). PLoS ONE 9: e110377.

Bolar, J.P., J.L. Norelli, K.W. Wong, C.K. Hayes, G.E. Harman and H.S. Aldwinckle (2000) Expression of endochitinase from Trichoderma harzianum in transgenic apple increases resistance to apple scab and reduces vigor. Phytopathology 90: 72-77.

Bolar, J.P., J.L. Norelli, G.E. Harman, S.K. Brown and H.S.Aldwinckle (2001) Synergistic activity of endochitinase and exochitinase from Trichoderma atroviride (T. harzianum) against the pathogenic fungus (Venturia inaequalis) in transgenic apple plants. Transgenic Res. 10: 533-543.

Borejsza-Wysocka,E., J.L.Norelli, H.S.Aldwinckle and M.Malnoy (2010) Stable expression and phenotypic impact of attacin E transgene in orchard grown apple trees over a 12 year period. BMC Biotechnol. 10: 41

Broggini, G.A.L., T. Wöhner, J. Fahrentrapp, T.D. Kost, H. Flachowsky, A. Peil, M.-V.Hanke, K. Richter, A. Patocchi and C. Gessler (2014) Engineering fire blight resistance into the apple cultivar 'Gala' using the FB_MR5 CC-NBS-LRR resistance gene of Malus $\times$ robusta 5. Plant Biotechnol. J. 12: 728-733.

Bus, V., E. Rikkerink, V.Caffier, C.E. Durel and K.M.Plummer (2011) Revision of the nomenclature of the differential host-pathogen interactions of Venturia inaequalis and Malus. Annu. Rev. Phytopathol. 49: 391-413.

Buti, M., L.Poles, D.Caset, P. Magnago, F. Fernández-Fernández, R.J.Colgan, R. Velasco and D.J. Sargent (2015) Identification and validation of a QTL influencing bitter pit symptoms in apple (Malus $\times$ domestica). Mol. Breed. 35: 29.

Calenge,F. and C.E. Durel (2006) Both stable and unstable QTLs for resistance to powdery mildew are detected in apple after four years of field assessments. Mol. Breed. 17: 329-339.

Carter,N. (2012) Petition for determination of nonregulate status: Arctic apples (Malus $\times$ domestica) event GD743 (Arctic Golden Delicious) and Gs784 (Arctic Granny Smith). Okanagao specialty fruits iNC. Summerland, BC VoH1ZO, Canada

Celton, J.M., J.J. Kelner, S. Martinez, A. Bechti, A. Touhami, M. James, C.E.Durel, F.Laurens and E.Costes (2014) Fruit self-thinning: a trait to consider for genetic improvement of apple tree. PLoS ONE 9: e91016.

Chagné,D., C.Krieger, M.Rassam, M.Sullivan, J.Fraser, C.André, M.Pindo, M. Troggio, S.E. Gardiner, R.A.Henry et al. (2012a) QTL and candidate gene mapping for polyphenolic composition in apple fruit. BMC Plant Biol. 12: 12. 
Chagné, D., R.N. Crowhurst, M. Troggio, M.W.Davey, B. Gilmore, C. Lawley, S. Vanderzande, R.P.Hellens, S. Kumar, A. Cestaro et al. (2012b) Genome-wide SNP detection, validation, and development of an 8K SNP array for apple. PLoS ONE 7: e31745.

Chagné, D., D. Dayatilake, R. Diack, M. Oliver, H. Ireland, A. Watson, S.E. Gardiner, J.W. Johnston, R.J. Schaffer and S. Tustin (2014) Genetic and environmental control of fruit maturation, dry matter and firmness in apple (Malus $\times$ domestica Borkh.). Hortic. Res. 1: 14046.

Chang, Y., R. Sun, H. Sun, Y.Zhao, Y.Han, D. Chen, Y.Wang, X.Zhang and Z.Han (2014) Mapping of quantitative trait loci corroborates independent genetic control of apple size and shape. Sci. Hortic. 174: 126-132.

Clark, M.D., J.J.Luby, J.M. Bradeen and V.G.M. Bus (2014) Identification of candidate genes at Rvi19 and Rvi20, two apple scab resistance loci in the 'Honeycrisp' apple (Malus $\times$ domestica). In Plant and Animal Genome XXII Conference. Plant and Animal Genome.

Costa, F., C.P.Peace, S. Stella, S. Serra, S. Musacchi, M.Bazzani, S.Sansavini and W.E.Van de Weg (2010) QTL dynamics for fruit firmness and softening around an ethylene-dependent polygalacturonase gene in apple (Malus $\times$ domestica Borkh.). J. Exp. Bot. 61: 3029-3039.

Costa,F., L.Cappellin, E.Zini, A.Patocchi, M.Kellerhals, M. Komjanc, C. Gessler and F. Biasioli (2013) QTL validation and stability for volatile organic compounds (VOCs) in apple. Plant Sci. 211: 1-7.

Costa, F., L. Cappellin, B. Farneti, A. Tardiello, A. Romano, C. Soukoulis, S. Sansavini, R. Velasco and F. Biasioli (2014) Advances in QTL mapping for ethylene production in apple (Malus $\times$ domestica Borkh.). Postharvest Biol. Technol. 87: 126-132.

Costa, F. (2015) MetaQTL analysis provides a compendium of genomic loci controlling fruit quality traits in apple. Tree Genet. Genomes 11: 819 .

Cova, V., P. Lasserre-Zuber, S. Piazza, A. Cestaro, R. Velasco, C.E. Durel and M.Malnoy (2015) High-resolution genetic and physical map of the Rvil (Vg) apple scab resistance locus. Mol. Breed. 35: 16.

Crevillén, P., H. Yang, X. Cui, C. Greeff, M. Trick, Q. Qiu, X.Cao and C. Dean (2014) Epigenetic reprogramming that prevents transgenerational inheritance of the vernalized state. Nature 515: 587-590.

Dayton, D.F., J.B. Mowry, L.F.Hough, C.H.Bailey, E.B.Williams, J. Janick and F.H.Emerson (1970) Prima-An early fall red apple with resistance to apple scab. Fruit Var. Hortic. Dig. 24: 20-22.

Desta,Z.A. and R. Ortiz (2014) Genomic selection: genome-wide prediction in plant improvement. Trends Plant Sci. 19: 592-601.

Devoghalaere, F., T. Doucen, B. Guitton, J. Keeling, W. Payne, T. Ling, J.J. Ross, I.C. Hallett, K. Gunaseelan, G.A. Dayatilake et al. (2012) A genomics approach to understanding the role of auxin in apple $($ Malus $\times$ domestica) fruit size control. BMC Plant Biol. 12: 7 .

Di Guardo, M., A. Tadiello, B.Farneti, G.Lorenz, D. Masuero, U. Vrhovsek, G. Costa, R. Velasco and F. Costa (2013) A multidisciplinary approach providing new insight into fruit flesh browning physiology in apple (Malus $\times$ domestica Borkh.). PLoS ONE 8: e78004.

Di Guardo, M., D. Micheletti, L. Bianco, H.J.J.Koehorst-van Putten, S. Longhi, F. Costa, M.J.Aranzana, R. Velasco, P.Arús, M. Troggio et al. (2015) ASSIst: an automatic SNP scoring tool for in- and outbreeding species. Bioinformatics 31: 3873-3874.

Dunemann, F., A. Peil, A.Urbanietz and T. Garcia (2007) Mapping of the apple powdery mildew resistance gene $P l l$ and its genetic association with an NBS-LRR candidate resistance gene. Plant Breed. 126: $476-481$.
Durel,C.E., C.Denancé and M.N. Brisset (2009) Two distinct major QTL for resistance to fire blight co-localize on linkage group 12 in apple genotypes 'Evereste' and Malus floribunda clone 821. Genome 52: 139-147.

Fahrentrapp, J., G.A. Broggini, M.Kellerhals, A.Peil, K. Richter, E. Zini and C. Gessler (2013) A candidate gene for fire blight resistance in Malus $\times$ robusta 5 is coding for a CC-NBS-LRR. Tree Genet. Genomes 9: 237-251.

Falginella, L., G. Cipriani, C. Monte, R. Gregori, R. Testolin, R. Velasco, M. Troggio and S. Tartarini (2015) A major QTL controlling apple skin russeting maps on the linkage group 12 of 'Renetta Grigia di Torriana'. BMC Plant Biol. 15: 150.

Fernández-Fernández,F., K.M.Evans, J.B.Clarke, C.L. Govan, C.M. James, S. Marić and K.R. Tobutt (2008) Development of an STS map of an interspecific progeny of Malus. Tree Genet. Genomes 4: 469-479.

Flachowsky, H., A. Peil, T. Sopanen, A. Elo and V.Hanke (2007) Overexpression of BpMADS4 from silver birch (Betula pendula Roth.) induces early-floweing in apple (Malus $\times$ domestica Borkh.). Plant Breed. 126: 137-145.

Flachowsky,H., P.M.Le Roux, A.Peil, A.Patocchi, K. Richter and M.V.Hanke (2011) Application of a high-speed breeding technology to apple (Malus $\times$ domestica) based on transgenic early flowering plants and marker-assisted selection. New Phytol. 192: 364377.

Flachowsky, H., C. Tränkner, I. Szankowski, S. Waidmann, M.V.Hanke, D. Treutter and T.C.Fischer (2012) RNA-mediated gene silencing signals are not graft transmissible from the rootstock to the scion in greenhouse-grown apple plants Malus sp. Int. J. Mol. Sci. 13: 9992-10009.

Fukasawa-Akada, T., T.Kudo, Y.Koga-Ban, T.Kon, A.Saito, Y. Hatsuyama, K. Shiratori, N. Nakazawa and M. Suzuki (1999) Identification of RAPD markers linked to the susceptibility gene for Alternaria blotch in apple. Breed. Res.1 (Suppl. 2): 17.

Fukasawa-Akada, T., K. Shiratori, T.Kudo, T.Kon, Y.Koga-Ban and M. Suzuki (2000a) RAPD-based linkage maps for Japanese apple cultivers. Breed. Res. 2 (Suppl. 2): 6.

Fukasawa-Akada, T., T.Kudo, K. Shiratori, T. Kon and Y.Hatsuyama (2000b) Inheritance of the sensitivity to Alternaria blotch and distribution of the linked markers in apple cultivars. Breed. Res. 2 (Suppl. 1): 301.

Fukasawa-Akada, T. (2003) Development of DNA markers linked to the susceptibility gene for Alternaria blotch in apple. Engeigakuzassi 72 (Suppl. 2): 60-61.

Galli, P., G.A.L. Broggini, M. Kellerhals, C. Gessler and A. Patocchi (2010a) High-resolution genetic map of the Rvi15 ( $V r 2)$ apple scab resistance locus. Mol. Breed. 26: 561-572.

Galli,P., A.Patocchi, G.A.L.Broggini and C.Gessler (2010b) The Rvi15 (Vr2) apple scab resistance locus contains three TIR-NBSLRR genes. Mol. Plant Microbe Interact. 23: 608-617.

Gardiner, S., J. Murdoch, S. Meech, R. Rusholme, H. Bassett, M. Cook, V.Bus, E. Rikkerink, A. Gleave, R. Crowhurst et al. (2003) Candidate resistance genes from an EST database prove a rich source of markers for major genes conferring resistance to important apple pests and diseases. Acta Hortic. 622: 141-151.

Gardiner, S., R. Rusholme, H.Bassett, V.Bus, W.Legg, M.Cook, C.Ranatunga, E.Rikkerink, A. Gleave and R. Crowhurst (2004) Conservation of markers around some genes in apple. In: Plant \& Animal Genome XII Conf, San Diego, CA, USA: http://www.intlpag.org/pag/12/abstracts/W23_PAG12_105.html

Gardiner, S.E., V.G.M.Bus, R.L.Rusholme, D.Chagné and E.H.A. 
Rikkerink (2007) CHAPTER 1 Apple. In: Kole, C. (ed.) Genome Mapping and Molecular Breeding in Plants, vol. 4. Fruits and Nuts, Springer.

Gardiner, S.E., J.L.Norelli, N.de Silva, G.Fazio, A.Peil, M. Malnoy, M.Horner, D. Bowatte, C.Carlisle, C. Wiedow et al. (2012) Putative resistance gene markers associated with quantitative trait loci for fire blight resistance in Malus 'Robusta 5' accessions. BMC Genet. 13: 25.

Guan, Y., C.Peace, D.Rudell, S. Verma and K.Evans (2015) QTLs detected for individual sugars and soluble solids content in apple. Mol. Breed. 35: 135.

Guitton, B., J.J.Kelner, R. Velasco, S. Gardiner, D.Chagné and E. Costes (2012) Genetic control of biennial bearing in apple. J. Exp. Bot. 63: 131-149.

Harada, T. (2010) Grafting and RNA transport via phloem tissue in horticultural plants. Sci. Hortic. 125: 545-550.

Hartung, F. and J. Schiemann (2014) Precise plant breeding using new genome editing techniques: opportunities, safety and regulation in the EU. Plant J. 78: 742-752.

Haywood, V., T.S. Yu, N.C. Huang and W.J. Lucas (2005) Phloem longdistance trafficking of GIBBERELLIC ACID-INSENSITIVE RNA regulates leaf development. Plant J. 42: 49-68.

Heap, B. (2013) Europe should rethink its stance on GM crops. Nature 498: 409

Hilton, I.B., A.M. D’Ippolito, C.M. Vockley, P.I. Thakore, G.E. Crawford, T.E. Reddy and C.A.Cersbach (2015) Epigenome editing by a CRISPR-Cas9-based acetyltransferase activates genes from promoters and enhancers. Nat. Biotechnol. 33: 510-517.

Holefors, A., Z.T. Xue and M.Welander (1998) Transformation of the apple rootstock M26 with the rolA gene and its influence on growth. Plant Sci. 136: 69-78.

Holme, I.B., T. Wendt and P.B. Holm (2013) Intragenesis and cisgenesis as alternatives to transgenic crop development. Plant Biotechnol. J. 11: 395-407.

Igarashi, M., H. Ogasawara, Y.Hatsuyama, A. Saito and M. Suzuki (2002) Introduction of rolC into Marubakaidou (Malus prunifolia Borkh. var. ringo Asami Mo-84-A) apple rootstock via Agrobacterium tumefaciens. Plant Sci. 163: 463-473.

James, C.M., J.B. Clarke and K.M. Evans (2004) Identification of molecular markers linked to the mildew resistance gene $\mathrm{Pl}-\mathrm{d}$ in apple. Theor. Appl. Genet. 110: 175-181.

James, C.M. and K.M. Evans (2004) Identification of molecular markers linked to the mildew resistance genes $P l-d$ and $P l-w$ in apple. Acta Hortic. 663: 123-127.

Jänsch, M., G.A. Broggini， J.Weger， V.G.Bus， S.E. Gardiner, H. Bassett and A.Patocchi (2015) Identification of SNPs linked to eight apple disease resistance loci. Mol. Breed. 35: 45.

Jia, H. and N. Wang (2014) Targeted genome editing of sweet orange using Cas9/sgRNA. PLoS ONE 9: e93806.

Joshi, S.G., J.G. Schaart, R. Groenwold, E. Jacobsen, H.J. Schouten and F.A.Krens (2011) Functional analysis and expression profiling of $H c r V f 1$ and HcrVf2 for development of scab resistant cisgenic and intragenic apples. Plant Mol. Biol. 75: 579-591.

Kanehira,A., K. Yamada, T. Iwaya, R. Tsuwamoto, A. Kasai, M. Nakazono and T.Harada (2010) Apple phloem cells contain some mRNAs transported over long distances. Tree Genet. Genomes 5: 635-642.

Kasai,A., S.Bai, T.Li and T.Harada (2011) Graft-transmitted siRNA signal from the root induces visual manifestation of endogenous post-transcriptional gene silencing in the scion. PLoS ONE 6: e16895.
Kasai,A. and T.Harada (2015) Epimutant induction as a new plant breeding technology. JARQ 49: 301-305.

Keller-Przybyłkowicz, S. and M.Korbin (2013) The history of mapping the apple genome. Folia Hort. 25: 161-168.

Kellerhals, M., A.Patocchi, B. Duffy and J.Frey (2008) Modern approaches for breeding high quality apples with durable resistance to scab, powdery mildew and fire blight. Ecofruit. 13th International Conference on Cultivation Technique and Phytopathological Problems in Organic Fruit-Growing: Proceedings, 18-20 February 2008, Weinsberg, Germany, 226-231.

Khan, M.A., B. Duffy, C. Gessler and A. Patocchi (2006) QTL mapping of fire blight resistance in apple. Mol. Breed. 17: 299-306.

Khan, M.A., C.E. Durel, B. Duffy, D. Drouet, M. Kellerhals, C. Gessler and A. Patocchi (2007) Development of molecular markers linked to the 'Fiesta' linkage group 7 major QTL for fire blight resistance and their application for marker-assisted selection. Genome 50: 568-577.

Khan, M.A., Y.F. Zhao and S.S. Korban (2012) Molecular mechanisms of pathogenesis and resistance to the bacterial pathogen Erwinia amylovora, causal agent of fire blight disease in Rosaceae. Plant Mol. Biol. Rep. 30: 247-260.

Khan, M.A., Y.F.Zhao and S.S. Korban (2013) Identification of genetic loci associated with fire blight resistance in Malus through combined use of QTL and association mapping. Physiol. Plant. 148: 344-353.

Khan, S.A., J.G. Schaart, J.Beekwilder, A.C.Allan, Y.M.Tikunov, E. Jacobsen and H.J. Schouten (2012a) The mQTL hotspot on linkage group 16 for phenolic compounds in apple fruits is probably the result of a leucoanthocyanidin reductase gene at that locus. BMC Res. Notes 5: 618.

Khan, S.A., P.Y.Chibon, R.C.de Vos, B.A.Schipper, E. Walraven, J. Beekwilder, T. van Dijk, R. Finkers, R.G. Visser, E.W. van de Weg et al. (2012b) Genetic analysis of metabolites in apple fruits indicates an mQTL hotspot for phenolic compounds on linkage group 16. J. Exp. Bot. 63: 2895-2908.

Ko, K., J.L.Norelli, J.P. Reynoird, H.S.Aldwinckle and S. Brown (2002) T4 lysozyme and attacin genes enhance resistance of transgenic 'Galaxy' apple against Erwinia amylovora. J. Amer. Soc. Hort. Sci. 127: 515-519.

Kon, T., N.Chiba, A. Fukasawa-Akada, T.Kudo and T.Sato (2005) Varietal difference of degree of browning and polyphenol concentrations in apple cultivars and selections. J. Japan Soc. Hort. Sci. 74 (Suppl. 1): 562.

Kon, T., S.Kasai, T.Kudo, T.Fukasawa-Akada and T.Sato (2008) Studies on characteristics of a non-browning apple cultivar 'Aori27' (1) Factors of non-browning. Hort. Res. (Japan) 7 (Suppl. 1): 56 .

Kon, T., T.Kudo, T.Fukasawa-Akada, S. Goto, T.Akahira, I. Machida, M. Shirakawa and N.Akita (2012) New apple cultivars, 'Aori9', 'Aori13', 'Aori15'. Bull. Apple Res. Inst. Aomori Prefec. Ind. Tec. Res. Cent. 36: 46-72.

Kotoda, N., H.Hayashi, M. Suzuki, M. Igarashi, Y.Hatsuyama, S. Kidou, T. Igasaki, M.Nishiguchi, K.Yano, T.Shimizu et al. (2010) Molecular characterization of FLOWERING LOCUS T-like genes of apple (Malus $\times$ domestica Borkh.). Plant Cell Physiol. 51: 561-575.

Kramer, M. and K. Redenbaugh (1994) Commercialization of a tomato with an antisense polygalacturonase gene: The FLAVR SAVR ${ }^{\mathrm{TM}}$ tomato story. Euphytica 79: 293-297.

Krens, F.A., J.G. Schaart, R. Groenwold, A.E. Walraven, T. Hesselink and J.T.Thissen (2011) Performance and long-term stability of the 
barley hordothionin gene in multiple transgenic apple lines. Transgenic Res. 20: 1113-1123.

Krens, F.A., J.G. Schaart,A.M. van der Burgh, I.E.M. Tinnenbroek-Capel, R. Groenwold, L.P.Kodde, G.A.L. Broggini, C.Gessler and H.J. Schouten (2015) Cisgenic apple trees; development, characterization, and performance. Front Plant Sci. 6: 286.

Kudo, T., T. Fukasawa-Akada, M. Igarashi, S. Goto, T. Kon and T. Sato (2013) New Apple cultivar, 'Aori25'. Hort. Res. (Japan) 13 (Suppl. 1): 256.

Kumar, S., D.Chagné, M.C.A.M.Bink, R.K.Volz, C. Whitworth and C. Carlisle (2012) Genomic selection for fruit quality traits in apple (Malus $\times$ domestica Borkh.). PLoS ONE 7: e36674.

Kumar,S., D.J.Garrick, M.C.Bink, C.Whitworth, D. Chagné and R.K. Volz (2013) Novel genomic approaches unravel genetic architecture of complex traits in apple. BMC Genomics 14: 393.

Kunihisa, M., S. Moriya, K.Abe, K. Okada, T. Haji, T. Hayashi, H. Kim, C.Nishitani, S. Terakami and T. Yamamoto (2014) Identification of QTLs for fruit quality traits in Japanese apples: QTLs for early ripening are tightly related to preharvest fruit drop. Breed. Sci. 64: 240-251.

Lambert, C. and D. Tepfer (1992) Use of Agrobacterium rhizogenes to create transgenic apple trees having an altered organogenic response to hormones. Theor. Appl. Genet. 85: 105-109.

Laurens, F., C.E. Durel, A. Patocchi, A.Peil, S.Salvi, S, Tartarini, R. Velasco and E. van de Weg (2010) Review on apple genetics and breeding programmes and presentation of a new European initiative to increase fruit breeding efficiency. Guoshu xuebao 27: 102107.

Le Roux, P.M., H. Flachowsky, M.V.Hanke, C. Gessler and A.Patocchi (2012) Use of a transgenic early flowering approach in apple (Malus $\times$ domestica Borkh.) to introgress fire blight resistance from cultivar Evereste. Mol. Breed. 30: 857-874.

Li,H., H.Flachowsky, T.C.Fischer, M.V.Hanke, G.Forkmann, D. Treutter, W.Schwab, T.Hoffmann and I.Szankowski (2007) Maize $L c$ transcription factor enhances biosysthesis of anthocyanins, distinct proanthocyanidins and phenylpropanoids in apple (Malus domestica Borkh.) Planta 226: 1243-1254.

Li, Y., L.Zhang, Z.Zhang, P.Cong and Z.M.Cheng (2011) A simple sequence repeat marker linked to the susceptibility of apple to Alternaria blotch caused by Alternaria alternata apple pathotype. J. Amer. Soc. Hort. Sci. 136: 109-115.

Longhi, S., M. Moretto, R. Viola, R. Velasco and F. Costa (2012) Comprehensive QTL mapping survey dissects the complex fruit texture physiology in apple (Malus $\times$ domestica Borkh.). J. Exp. Bot. 63: 1107-1121.

Longhi, S., M.T.Hamblin, L.Trainotti, C.P.Peace, R. Velasco and F. Costa (2013a) A candidate gene based approach validates $M d$ $P G 1$ as the main responsible for a QTL impacting fruit texture in apple (Malus $\times$ domestica Borkh). BMC Plant Biol. 13: 37.

Longhi, S., L. Cappellin, W. Guerra and F. Costa (2013b) Validation of a functional molecular marker suitable for marker-assisted breeding for fruit texture in apple (Malus $\times$ domestica Borkh.). Mol. Breed. 32: 841-852.

Lusser, M., C. Parisi, D. Plan and E. Rodriguez-Cerezo (2012) Deployment of new biotechnologies in plant breeding. Nat. Biotechnol. 30: 231-239.

Malnoy, M., E.E.Boresjza-Wysocka, J.L.Norelli, M.A.Flaishman, D. Gidoni and H.S.Aldwinckle (2010) Genetic transformation of apple (Malus $\times$ domestica) without use of a selectable marker gene. Tree Genet. Genomes 6: 423-433.

Marić, S., M.Lukić, R. Cerović, M. Mitrović and R. Bošković (2010)
Application of molecular markers in apple breeding. Genetika 42: 359-375.

Marondedze,C. and L. Thomas (2013) Genes and quality trait loci (QTLs) associated with firmness in Malus $\times$ domestica. Afr. J. Biotechnol. 12: 996-1003.

Mellidou, I., D. Chagne, W.Laing, J.Keulemans and M. Davey (2012) Allelic variation in paralogs of GDP-L-galactose phosphorylase is a major determinant of vitamin $\mathrm{C}$ concentrations in apple fruit. Plant Physiol. 160: 1613-1629.

Morimoto, T., Y.Hiramatsu and K. Banno (2013) A major QTL controlling earliness of fruit maturity linked to the red leaf/red flesh trait in apple cv. 'Maypole'. J. Japan Soc. Hort. Sci. 82: 97-105.

Morimoto, T., K. Yonemushi, H. Ohnishi and K. Banno (2014) Genetic and physical mapping of QTLs for fruit juice browning and fruit acidity on linkage group 16 in apple. Tree Genet. Mol. Breed. 4: $1-10$.

Morimoto, T. and K. Banno (2015) Genetic and physical mapping of Co, a gene controlling the columnar trait of apple. Tree Genet. Genomes 11: 807.

Moriya, S., H. Iwanami, S. Takahashi, N. Kotoda, K. Suzaki and K. Abe (2008) Evaluation and inheritance of crown gall resistance in apple rootstocks. J. Japan. Soc. Hort. Sci. 77: 236-241.

Moriya, S., H. Iwanami, S. Takahashi, N.Kotoda, K. Suzaki, T. Yamamoto and K.Abe (2010) Genetic mapping of the crown gall resistance gene of the wild apple Malus sieboldii. Tree Genet. Genomes 6: 195-203.

Moriya, S., S. Terakami, H. Iwanami, T. Haji, K. Okada, T. Yamamoto and K.Abe (2011) Genetic mapping and marker-assisted selection of the gene conferring susceptibility to Alternaria blotch caused by Alternaria alternate apple pathotype in apple. In: XIII Eucarpia Symposium on Fruit Breeding and Genetics 976: 555-560.

Moriya, S., K. Okada, T. Haji, S. Terakami, M. Kunihisa, T. Yamamoto and K.Abe (2012a) QTL analysis of Alternaria blotch susceptibility derived from apple cultivar 'Orin'. Hort. Res. (Japan) 11 (Suppl. 2): 123 .

Moriya, S., K. Okada, T.Haji, S. Terakami, T. Yamamoto and K.Abe (2012b) Marker-assisted selection of apple seedlings using DNA markers linked to Alternaria blotch resistance and fruit skin color. Hort. Res. (Japan) 11 (Suppl. 2): 261.

Moriya, S., K. Okada, T.Haji, T. Yamamoto and K.Abe (2012c) Fine mapping of $\mathrm{Co}$, a gene controlling columnar growth habit located on apple (Malus $\times$ domestica Borkh.) linkage group 10. Plant Breed. 131: 641-647.

Moriya, S., K. Okada, S. Terakami, T. Yamamoto and K.Abe (2013) Fine mapping of Alt, a gene conferring Alternaria blotch susceptibility in apple. Hort. Res. (Japan) 12 (Suppl. 1): 58.

Moriya, S., H. Iwanami, T. Haji, K. Okada, M. Yamada, T. Yamamoto and K.Abe (2015) Identification and genetic characterization of a quantitative trait locus for adventitious rooting from apple hardwood cuttings. Tree Genet. Genomes 11: 59.

Mudge, K., J. Janick, S. Scofield and E.E. Goldschmidt (2009) A history of grafting. Horticulture Reviews, vol. 35. John Wiley \& Son, Inc, pp. 437-493.

Murata, M., M. Haruta, N. Murai, N. Tanikawa, M.Nishimura, S. Homma and Y. Itoh (2000) Transgenic apple (Malus $\times$ domestica) shoot showing low browning potential. J. Agric. Food Chem. 48: 5243-5248.

Nakamura, K., N. Yamagishi, M. Isogai, S.Komori, T. Ito and N. Yoshikawa (2011) Seed and pollen transmission of apple latent spherical virus in apple. J. Gen. Plant Pathol. 77: 48-53.

Noro, S., T.Sato, T.Kon, T.Akada, T.Kudo and S.Kasai (2009) 
Non-browning apple, method for producing the same, and drink and food using the same. U.S. Patent 8704050 B2 2014-4-22.

Okada, K., S. Moriya, T.Haji, S. Terakami, T. Yamamoto and K.Abe (2011) Genetic mapping of the gene for alpha subunit of chloroplast chaperonin associated with susceptibility to Alternaria. Hort. Res. (Japan) 10 (Suppl. 2): 373.

O'Rourke, D. (2003) Changing dynamics of world fruit markets. Compact Fruit Tree 36: 12-14.

Padmarasu, S., D.J.Sargent, M. Jaensch， M.Kellerhals， S. Tartarini, R. Velasco, M. Troggio and A. Patocchi (2014) Fine-mapping of the apple scab resistance locus Rvil2 ( $\mathrm{Vb}$ ) derived from 'Hansen's baccata \# 2'. Mol. Breed. 34: 2119-2129.

Parisi,L., F.Laurens, F. Didelot, K.Evans, C.Fischer, V.Fouillet, F. Gennari, H.Kemp, M.Lateur, A. Patocchi et al. (2006) Geographical distribution of Venturia inaequalis strains virulent to the $V f$ gene in Europe. IOBC-WPRS Bulletin 29: 49-52.

Parravicini, G., C. Gessler, C.Denancé, P.Lasserre-Zuber, E. Vergne, M. Brisset, A.Patocchi, C. Durel and G.A.L. Broggini (2011) Identification of serine/threonine kinase and nucleotide-binding siteleucine-rich repeat (NBS-LRR) genes in the fire blight resistance quantitative trait locus of apple cultivar 'Evereste'. Mol. Plant Pathol. 12: 493-505.

Patocchi,A., A.Frei, J.E. Frey and M.Kellerhals (2009) Towards improvement of marker assisted selection of apple scab resistant cultivars: Venturia inaequalis virulence surveys and standardization of molecular marker alleles associated with resistance genes. Mol. Breed. 24: 337-347.

Peer, R., G. Rivlin, S. Golobovitch, M. Lapidot, A. Gal-On, A. Vainstein, T.Tzfira and M.A. Flaishman (2015) Targeted mutagenesis using zinc-finger nucleases in perennial fruit trees. Planta 241: 941-951.

Peil,A., T.Garcia-Libreros, K. Richter, F.C.Trognitz, B. Trognitz, M.V.Hanke and H.Flachowsky (2007) Strong evidence for a fire blight resistance gene of Malus robusta located on linkage group 3. Plant Breed. 126: 470-475.

Pereira-Lorenzo, S., A.M. Ramos-Cabrer and M. Fischer (2009) Breeding Apple (Malus $\times$ domestica Borkh.). In: Jain, S.M. and P.M. Priyadarshan (eds.) Breeding Plantation Tree Crops: Temperate Species, Springer Science+Business Media, LLC2009.

Potts, S.M., M.A. Khan, Y.Han, M.M. Kushad and S.S. Korban (2014) Identification of quantitative trait loci (QTLs) for fruit quality traits in apple. Plant Mol. Biol. Rep. 32: 109-116.

Puite, K.J. and J.G.Schaart (1996) Genetic modification of the commercial apple cultivars Gala, Golden Delicious and Elstar via an Agrobacterium tumefaciens-mediated transformation method. Plant Sci. 119: 125-133.

Rikkerink, H.A., E.M.Hilario-Andrade, A.P.Dare, S.E. Gardiner, M. Yoon and V.G.M.Bus (2010) Resistance gene and uses thereof. U.S. Patent Application No. 12/740,318, Publication No. US 2010/0306875 A1. 02 December 2010.

Saito, K. and K. Takeda (1984) Genetic analysis of resistance to Alternaria Blotch (Alternaria mali Roberts) in apple: Studies on the breeding of the apple. VIII. Breed. Sci. 34: 197-209.

Schaart, J.G., I.E.M. Tinnenbroek-Capel and F.A. Krens (2011a) Isolation and characterization of strong gene regulatory sequences from apple, Malus $\times$ domestica. Tree Genet. Genomes 7: 135-142.

Schaart, J.G., F.A. Krens, A.-M.A. Wolters and R.G.F. Visser (2011b) Transformation methods for obtaining marker-free genetically modified plants. Plant Transformation Technologies 15: 229-242.

Schouten, H.J., J.Brinkhuis, A. van der Burgh, J.G. Schaart, R. Groenwold, G.A.L.Broggini and C.Gessler (2014) Cloning and functional characterization of the Rvil5 ( $V r 2)$ gene for apple scab resistance. Tree Genet. Genomes 10: 251-260.

Smolka,A., X.Y.Li, C.Heikelt, M. Welander and L.H.Zhu (2010) Effects of transgenic rootstocks on growth and development of non-transgenic scion cultivars in apple. Transgenic Res. 19: 933948.

Soriano, J.M., M. Madduri, J.G. Schaart, A. van der Burgh, M.P.W. van Kaauwen, L. Tomic, R. Groenwold, R. Velasco, E. van de Weg and H.J. Schouten (2014) Fine mapping of the gene Rvil (V25) for broad-spectrum resistance to apple scab, and development of a linked SSR marker suitable for marker-assisted breeding. Mol. Breed. 34: 2021-2032.

Souleyre, E.J., D. Chagné, X. Chen, S. Tomes, R.M. Turner, M.Y. Wang, R. Maddumage, M.B.Hunt, R.A.Winz, C. Wiedow et al. (2014) The AAT1 locus is critical for the biosynthesis of esters contributing to 'ripe apple' flavour in 'Royal Gala' and 'Granny Smith' apples. Plant J. 78: 903-915.

Sun, R., H.Li., Q.Zhang, D.Chen, F. Yang, Y.Zhao, Y, Wang, Y.Han, X.Zhang and Z.Han (2014) Mapping for quantitative trait loci and major genes associated with fresh-cut browning in apple. HortScience 49: 25-30.

Sun, R., Y.Chang, F. Yang, Y.Wang, H.Li, Y.Zhao, D.Chen, T.Wu, X. Zhang and Z. Han (2015) A dense SNP genetic map constructed using restriction site-associated DNA sequencing enables detection of QTLs controlling apple fruit quality. BMC Genomics 16: 747.

Tabira,H. and H. Otani (2004) Japan Patent Kokai 2004-283002 (2004.10.14).

Telias,A., K.Lin-Wang, D.E. Stevenson, J.M.Cooney, R.P.Hellens, A.C.Allan, E.E.Hoover and J.M.Bradeen (2011) Apple skin patterning is associated with differential expression of MYB10. BMC Plant Biol. 11: 93.

Terras, F.R.G., H.M.E. Schoofs, K. Thevissen, R.W.Osborn, J. Vanderleyden, B.P.A.Cammue and W.F. Broekaert (1993) Synergistic enhancement of the antifungal activity of wheat and barley thionins by radish and oilseed rape $2 \mathrm{~S}$ albumins and by barley trypsin inhibitors. Plant Physiol. 103: 1311-1319.

Thieme, C.J., M.Rojas-Triana, E. Stecyk, C.Schudoma, W.Zhang, L. Yang, M. Miñambres, D. Walther, W.X. Schulze, J.Paz-Ares et al. (2015) Endogenous Arabidopsis messenger RNAs transported to distant tissues. Nature Plants 1: 1-7.

Vainstein,A., I. Marton, A.Zuker, M.Danziger and T.Tzfira (2011) Permanent genome modifications in plant cells by transient viral vectors. Trends Biotechnol. 29: 363-369.

Vanblaere, T., H.Flachowsky, C. Gessler and G.A.Broggini (2014) Molecular characterization of cisgenic lines of apple 'Gala' carrying the Rvi6 scab resistance gene. Plant Biotechnol. J. 12: 2-9.

Velasco, R., A.Zharkikh, J.Affourtit, A.Dhingra, A. Kalyanaraman, P.Fontana, S.K. Bhatnagar, M. Troggio, D. Pruss, S. Salvi et al. (2010) The genome of the domesticated apple (Malus $\times$ domestica Borkh.). Nat. Genet. 42: 833-839.

Verdu, C.F., S.Guyot, N. Childebrand, M. Bahut, J.M.Celton, S. Gaillard, P.Lasserre-Zuber, M.Troggio, D. Guilet and F.Laurens (2014) QTL analysis and candidate gene mapping for the polyphenol content in cider apple. PLoS ONE 9: e107103.

Vinatzer, B.A., A. Patocchi, L. Gianfranceschi, S. Tartarini, H.B.Zhang, C. Gessler and S. Sansavini (2001) Apple contains receptor-like genes homologous to the Cladosporium fulvum resistance gene family of tomato with a cluster of genes cosegregating with $\mathrm{Vf}$ apple scab resistance. Mol. Plant Microbe Interact. 14: 508-515.

Wakasa, Y., H. Kudo, R. Ishikawa, S.Akada, M. Senda, M. Niizeki and T.Harada (2006) Low expression of an endopolygalacturonase gene in apple fruit with long term storage potential. Postharvest 
Biol. Technol. 39: 193-198.

Weigl, K., S. Wenzel, H.Flachowsky, A.Peil and M.V.Hanke (2015) Integration of BpMADS4 on various linkage groups improves the utilization of the rapid cycle breeding system in apple. Plant Biotechnol. J. 13: 246-258.

Welander, M., N. Pawlicki, A. Holefors and F. Wilson (1998) Genetic transformation of the apple rootstock M26 with the rolB gene and its influence on rooting. J. Plant Physiol. 153: 371-380.

Würdig, J., H. Flachowsky, A. Saß, A.Peil and M.V.Hanke (2015) Improving resistance of different apple cultivars using the Rvi6 scab resistance gene in a cisgenic approach based on the Flp/FRT recombinase system. Mol. Breed. 35: 95.

Xu, H., W.Zhang, M. Li, T. Harada, Z.Han and T. Li (2010) Gibberellic acid insensitive mRNA transport in both directions between stock and scion in Malus. Tree Genet. Genomes 6: 1013-1019.

Xu,H., R. Iwashiro, T.Li and T.Harada (2013) GIBBERELLIC ACID INSENSITIVE transcript transported from stock is translated and attenuates GA response in the scion. BMC Plant Biol. 13: 165.

Xu, K. (2013) An overview of Arctic apples: Basic facts and characteristics. New York Fruit Quarterly 21: 8-10.

Yamagishi, N., S. Sasaki, K. Yamagata, S. komori, M. Nagase, M. Wada, T. Yamamoto and N. Yoshikawa (2011) Promotion of flowering and reduction of a generation time in apple seedlings by ectopical expression of the Arabidopsis thaliana FT gene using the Apple latent spherical virus vector. Plant Mol. Biol. 75: 193-204.

Yamagishi, N., R. Kishigami and N. Yoshikawa (2014) Reduced generation time of apple seedlings to within a year by means of a plant virus vector: a new plant-breeding technique with no transmission of genetic modification to the next generation. Plant Biotechnol. J. 12: 60-68.

Yang, Y.Z., L. Mao, Y.Jittayasothorn, Y.Kang, C.Jiao, Z.Fei and G.Y.Zhong (2015) Messenger RNA exchange between scions and rootstocks in grafted grapevines. BMC Plant Biol. 15: 251.

Zhang, X., L.Wang, X.Chen, Y.Liu, R.Meng, V.Wang and Z.Zhao (2014) A and MdMYB1 allele-specific markers controlling apple (Malus $\times$ domestica Borkh.) skin color and suitability for markerassisted selection. Genet. Mol. Res. 13: 9103-9114.

Zhao, D. and G. Song (2014) Rootstock-to-scion transfer of transgenederived small interfering RNAs and their effect on virus resistance in nontransgenic sweet cherry. Plant Biotechnol. J. 12: 1319-1328.

Zhu, L.H., A.Ahlman, X.Y.Li and M. Welander (2001a) Integration of the rolA gene into the genome of the vigorous apple rootstock A2 reduced plant height and shortened internodes. J. Hort. Sci. Biotech. 76: 758-763.

Zhu, L.H., A. Holefors, A.Ahlman, Z.T. Xue and M. Welander (2001b) Transformation of the apple rootstock M.9/29 with the rolB gene and its influence on rooting and growth. Plant Sci. 160: 433-439. 